\title{
Climate forcing of the spring bloom in Chesapeake Bay
}

\author{
W. David Miller ${ }^{1, *}$, Lawrence W. Harding Jr. ${ }^{1,2}$ \\ ${ }^{1}$ Horn Point Laboratory, University of Maryland Center for Environmental Science, Box 775, Cambridge, Maryland 21613, USA \\ ${ }^{2}$ Maryland Sea Grant College, University of Maryland Center for Environmental Science, 4321 Hartwick Road, Suite 300, \\ College Park, Maryland 20740, USA
}

\begin{abstract}
Interannual variability of the spring phytoplankton bloom is strongly expressed in estuarine ecosystems such as Chesapeake Bay. Quantifying this variability is essential to resolve ecosystem responses to eutrophication from variability imposed by climate. We developed a 'synoptic climatology' from surface sea-level pressure (SLP) maps to categorize and quantify atmospheric circulation patterns and address climate forcing of phytoplankton dynamics in the Bay. The 10 patterns we identified had unique frequencies-of-occurrence and associated meteorological conditions (i.e. precipitation, temperature, wind speed and direction). Four measures of phytoplankton biomass, surface chlorophyll a $(B)$, euphotic layer chlorophyll a $\left(B_{\mathrm{eu}}\right)$, water column chlorophyll a $\left(B_{\mathrm{wc}}\right)$, and total biomass $\left(B_{\text {tot }}\right)$, were obtained from remotely sensed ocean color data spanning 16 yr (1989 to 2004) combined with concurrent shipboard data. Years with more frequent warm/wet weather patterns had spring blooms that reached peak biomass farther seaward in the estuary, were greater in magnitude, occurred later in the spring, and covered a larger area than years with a predominance of cool/dry weather patterns. Frequencies of winter weather patterns were used to forecast spring $B, B_{\text {eu }}, B_{\mathrm{wc}}$ and $B_{\text {tot, }}$ explaining between 23 and $89 \%$ of the variance in the regional time-series. Residuals from these models did not show time-trends attributable to either accelerating eutrophication or management actions intended to decrease nutrient loadings. These findings extend our understanding of climatic influences on phytoplankton dynamics in the Bay by quantifying the effects of synoptic climate variability on spring bloom intensity, thereby supporting forecasts of seasonal phytoplankton biomass based on sub-continental scale weather patterns in this mid-Atlantic estuary.
\end{abstract}

KEY WORDS: Spring bloom - Phytoplankton dynamics - Synoptic climatology $\cdot$ Chesapeake Bay

- Resale or republication not permitted without written consent of the publisher

\section{INTRODUCTION}

Climate variability strongly influences marine ecosystems (Stenseth et al. 2002), exemplified by basinscale biological responses to the El Niño-Southern Oscillation (ENSO; Chavez et al. 1999), and the North Atlantic Oscillation (NAO; Ottersen et al. 2001). These indices provide simple measures of climate variability and reduce the complexity associated with multiple individual meteorological measurements (i.e. temperature, precipitation, wind speed, etc.; Stenseth et al. 2002). Global data from remotely sensed ocean color and temperature observations, coupled to climate indices, have contributed to our understanding of ocean-atmosphere interactions that drive phytoplankton dynamics (Behrenfeld et al. 2001). In some areas, however, large-scale climate indices are not strongly expressed and sub-continental processes assume greater importance in forcing local meteorological conditions (Stenseth et al. 2003). An alternative approach that provides a comprehensive measure of climate variability, while retaining local relevance, is to construct a regional 'synoptic climatology' (cf. Yarnal 1993). 
Interannual variability in phytoplankton biomass and primary productivity is strongly expressed in temperate estuaries, and multiple causes including freshwater flow, nutrient loading, and turbidity underlie that variability (Boynton et al. 1982). To this end, the proximal effects of freshwater flow on phytoplankton dynamics have been documented for a number of estuarine systems, including the Hudson River (Malone 1977), San Francisco Bay (Cloern et al. 1983), the Neuse River (Mallin et al. 1993), and the Loire River estuary (Relexans et al. 1988). These studies have shown that the magnitude of phytoplankton biomass, measured as chlorophyll a (chl a), often co-varies with flow and attendant properties, but the relationships are generally dependent on characteristics unique to individual systems (e.g. circulation, residence time, morphometry, tides, nutrient and sediment loading). While we recognize the important role that flow plays in determining spatial and temporal dynamics of phytoplankton in estuaries, indices of regional climate may provide more comprehensive measures of environmental influences. A missing element of our understanding is a quantitative description of the role of regional climate in forcing variability of phytoplankton biomass, such as has emerged for some parts of the global ocean using ENSO and NAO indices. This is an important area of research as we attempt to predict effects of climate change and nutrient enrichment on estuarine and coastal ecosystems (Cloern 2001).

Freshwater flow into Chesapeake Bay is maximal in winter-spring, as it is in many temperate estuaries; dominated by the freshet of the Susquehanna River that largely determines gradients of light and nutrients along the north-south axis of the Bay (Harding et al. 1986). The timing, position, magnitude, and extent of the winter-spring diatom bloom are determined in large part by the winter-spring flow (Malone 1992, Harding 1994), and variability of flow during this period has recently been linked to synoptic-scale climate for winter (Miller et al. 2006). An abundant literature supports the interaction of atmospheric circulation, precipitation, and freshwater flow (Cayan \& Peterson 1989, McCabe \& Ayers 1989), including findings for the Susquehanna River (Crane \& Hewitson 1998, Najjar 1999). We suggest that a major source of interannual variability of spring bloom intensity, expressed by several measures of phytoplankton biomass, can be traced to differences in the frequency and types of winter weather patterns prevailing in the Bay's watershed in a given year.

The work described herein relates winter climate variability at the synoptic scale to spring phytoplankton dynamics in Chesapeake Bay through links to freshwater flow and other environmental parameters influenced by climate (Miller et al. 2006). We tested the hypothesis that interannual differences in the frequencies of winter weather types identified using a synoptic climatology classification represent the predominant source of variability for spring phytoplankton biomass in Chesapeake Bay. To address this hypothesis we (1) classified and quantified variability in atmospheric circulation patterns in the region using a synoptic climatology classification; (2) quantified the position, magnitude, timing, and extent of the spring bloom using a 16 yr time-series of surface chl a $(B)$, euphotic layer chl a $\left(B_{\text {eu }}\right)$, water column chl a $\left(B_{\mathrm{wc}}\right)$, and total biomass $\left(B_{\text {tot }}\right)$ from aircraft remote sensing; $(3)$ developed multiple regression models using the frequencies of predominant weather patterns as independent variables and 4 biomass measures as dependent variables; (4) examined residuals of spring phytoplankton biomass after removal of the climate signal to resolve trends.

\section{MATERIALS AND METHODS}

Synoptic climatology. Regional-scale climate variability was quantified using an eigenvector-based, map-pattern, synoptic climatology classification, described in Yarnal (1993) and Miller et al. (2006). We obtained $5^{\circ} \times 5^{\circ}$ latitude - longitude gridded, sea-level pressure (SLP) data from the National Center for Atmospheric Research (NCAR; http://dss.ucar.edu) to create a 48-point $(6 \times 8)$ grid of SLP data covering the area 25 to $50^{\circ} \mathrm{N}$ latitude and 65 to $100^{\circ} \mathrm{W}$ longitude. Principal component analysis (PCA) was performed on a correlation matrix of daily SLP against time (d) to reduce spatial variability in the SLP data from the original 48 points to a smaller number (7) of new variables that explained the majority of the variability (90\%) in the original data. Those 7 variables were submitted to a 2-stage clustering procedure to group the data into similarly occurring modes of variance that related to similar atmospheric circulation patterns. The first stage of the clustering procedure (average linkage) was used to determine the number of clusters (10) that made up a significant fraction ( $>2 \%$ ) of the total number of days, and to determine 'seed' values for the subsequent $k$-means clustering procedure. The second clustering technique ( $k$-means) regrouped the data into one of 10 dominant seed clusters determined to be important using the average linkage clustering technique. Average SLP maps for each of the 10 clusters were then produced by taking the mean value for each grid point within the daily maps. The seasonal frequencies-ofoccurrence of each weather pattern for every year were then computed for use in multiple regression models.

Remotely sensed data. Biomass, $B\left(\mathrm{mg} \mathrm{chl} a \mathrm{~m}^{-3}\right)$, was determined for the surface layer using aircraft 
ocean color measurements from light aircraft (Harding et al. 1994, 1995). Flights were conducted $\sim 20$ to 30 times per year (March to October) on a set of tracks covering the mainstem Bay (Fig. 1). Geo-referenced data were collected from an altitude of $150 \mathrm{~m}$ at a ground speed of approximately $50 \mathrm{~m} \mathrm{~s}^{-1}$ using multispectral radiometers. NASA's Ocean Data Acquisition System (ODAS) consisting of 3 nadir-viewing radiometers $(460,490$, and $520 \mathrm{~nm})$ with $15 \mathrm{~nm}$ bandwidths and a $2^{\circ}$ field-of-view was used from 1989 to 1995 . Successive versions of the commercial Sea-viewing Wide Field-of-view Sensor (SeaWiFS) Aircraft Simulator (SAS II, III: Satlantic) with $10 \mathrm{~nm}$ bandwidths, $3.5^{\circ}$ field-of-view, and 7 and 13 wavelengths, respectively (SAS II 412, 443, 490, 510, 555, 670, and $683 \mathrm{~nm}$; SAS III 380, 400, 412, 443, 470, 490, 510, 555, 670, 685, 700, 780 , and $865 \mathrm{~nm}$ ) were used from 1995 to 2004.

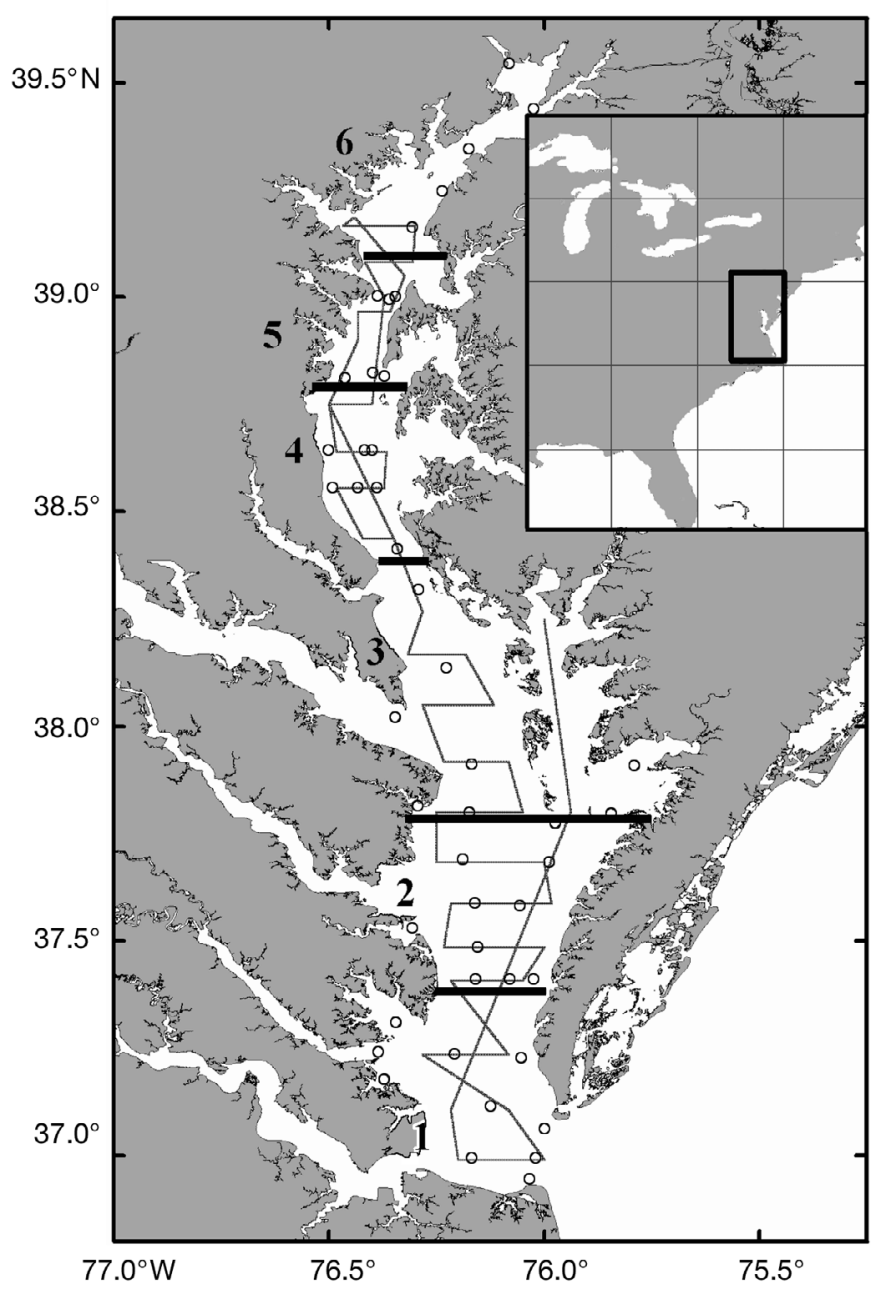

Fig. 1. Chesapeake Bay showing flight lines from Chesapeake Bay Remote Sensing Program. Thick, black lines and Nos. 1 to 6: regions; (O) Chesapeake Bay Program stations. Regions $=1$ : $36.95-37.40^{\circ} \mathrm{N}_{i} \quad 2: \quad 37.41-37.80^{\circ} \mathrm{N}_{;} \quad 3: \quad 37.81-38.40^{\circ} \mathrm{N}_{i} \quad 4$ : $38.41-38.80^{\circ} \mathrm{N} ; 5: 38.81-39.10^{\circ} \mathrm{N} ; 6: 39.11-39.66^{\circ} \mathrm{N}$
$B$ was computed using a spectral curvature algorithm (Campbell \& Esaias 1983) applied to water-leaving radiances at 460,490 , and $520 \mathrm{~nm}$ for ODAS, and 443, 490, and $555 \mathrm{~nm}$ for SAS II and III. Radiometric calibrations were made at NASA for ODAS and at Satlantic for SAS II and III. Retrievals of $B$ relied on local algorithms developed from matchups with concurrent in situ measurements from monitoring cruises of EPA's Chesapeake Bay Program (CBP; www.chesapeake bay.net/) and our own cruises. We defined a match as $\pm 12 \mathrm{~h}$ on the same day, $\pm 0.01^{\circ}$ latitude and $\pm 0.005^{\circ}$ longitude (Harding et al. 1994, 1995). The working equation retrieved $\log _{10} B$ with an RMS error of 0.21 (log units). Flight data were interpolated onto a $1 \mathrm{~km}^{2}$ grid for visualization and further analyses using a 2-dimensional, inverse-distance-squared, octant search (Harding et al. 1994, 1995).

Integrated biomass ( $\boldsymbol{B}_{\mathrm{eu}}, \boldsymbol{B}_{\mathrm{wc}}$ and $\left.\boldsymbol{B}_{\mathrm{tot}}\right) . B_{\mathrm{eu}}(\mathrm{mg} \mathrm{chl} a$ $\mathrm{m}^{-2}$ ) was computed for each grid cell as the product of $B$ and euphotic-layer depth $\left(Z_{\mathrm{p}}\right)$, estimated as the $1 \%$ isolume from Secchi depth for the closest CBP cruise

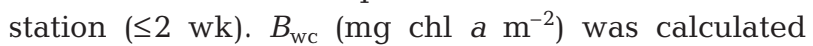
from log-log regressions of bathymetrically-weighted integrals of chl a from vertical profiles, $\left\langle B_{\mathrm{wc}}\right\rangle$, on $B$ developed with CBP data (cf. Harding et al. 1994). Analysis of variance showed statistically significant differences in the slopes of regression equations for different years; accordingly we used equations developed for each year to generate $\left\langle B_{\mathrm{wc}}>\right.$ from remotely sensed $B$. Back-transformed $\left\langle B_{\mathrm{wc}}\right\rangle$ data were combined with depth $(H)$ for each grid cell from a digital bathymetry to give $B_{\mathrm{wc}}$. All 3 biomass measures were log-normally distributed and were $\log _{10}$-transformed for all analyses and back-transformed for graphical display. Total biomass, $B_{\text {tot }}$ (metric tons chl a), was calculated as the sum of all $B_{\mathrm{wc}}$ measurements for the entire Bay. Data from depths greater than the median bay depth $(7.7 \mathrm{~m})$ were used to calculate means for regional regression models.

Data were analyzed for 6 regions of the mainstem bay defined by latitude (Harding 1994; present Fig. 1). Regional means for spring (April and May) were computed for $B, B_{\mathrm{eu}}, B_{\mathrm{wc}}$ and $B_{\mathrm{tot}}$ from flights spanning 1989 to 2004. Data from 5 to 15 flights were obtained each spring, depending on weather and aircraft availability. Shipboard data were substituted for aircraft data for spring 1996 due to instrument malfunctions. No statistically significant $(\tau>0.05$, Mann-Kendall trend test) trends were observed in any of the regional time-series.

Ancillary data. Temperature and precipitation data were obtained from the National Climate Data Center (NCDC $;$ http://cdo.ncdc.noaa.gov). Divisional data from the 8 climatic regions within the Susquehanna River basin (Pennsylvania Divisions 4, 5, 6, 7, 8; Mary- 


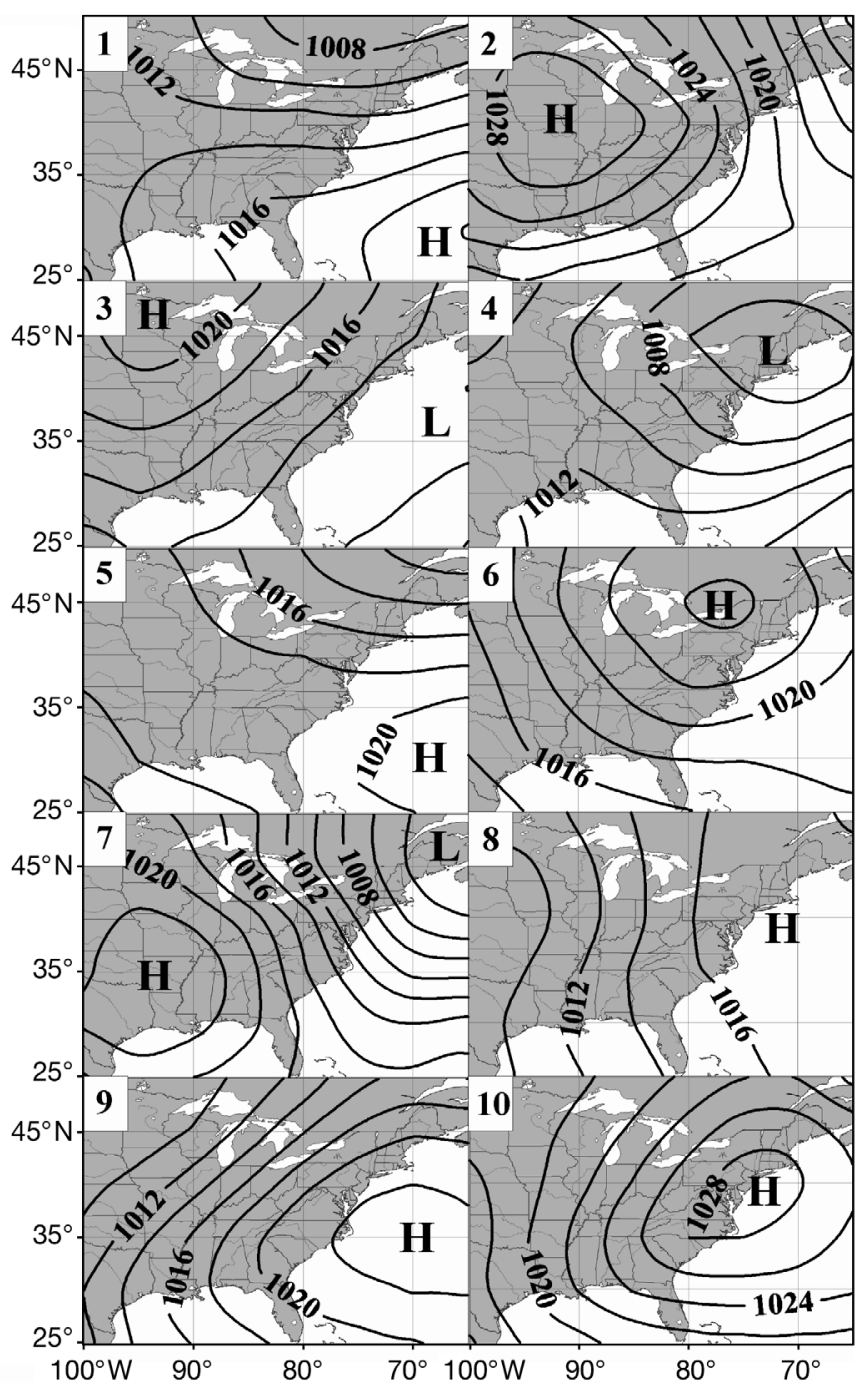

Fig. 2. Average sea-level pressure maps for each cluster. Weather pattern number is in upper left-hand corner; $\mathrm{H}, \mathrm{L}$ : centers of high and low pressure regions, respectively; contour lines: regions of constant pressure (mb). (Weather patterns are described in Table 1)

solved inorganic nitrogen; DIN) were obtained from CBP water quality monitoring cruises.

Regression analyses. Multiple linear regression models were developed to investigate the relationship between regional phytoplankton biomass in spring and the frequency-of-occurrence of winter weather patterns described by the synoptic climatology. To clarify, regional measures of phytoplankton biomass in spring were the dependent variables, weather pattern frequencies were the independent variables, and each year was an observation $(\mathrm{n}=16)$. Selection of independent variables for inclusion in each model was determined by the combination of weather patterns that explained the maximum amount of variance in the data set while producing a significant model $(p<0.05)$. Explained variance was measured as the adjusted $r^{2}$ to account for the increased variance explained with increasing numbers of explanatory (independent) variables. Multicolinearity of the independent variables was checked with the variance inflation factor (VIF) diagnostic in SAS (Cody \& Smith 2005); no variable in the models had a VIF $>5$ (values $>10$ indicate serious problems with multi-colinearity). Testing for trends in residuals of the multiple linear regression models was done with the Mann-Kendall trend test. All statistics were performed in SAS Version 9.1 (SAS Institute). land Division 6; New York Divisions 1, 2) were weighted by area to produce a single estimate of temperature or precipitation. Climate division data were used to provide comprehensive measures of temperature and precipitation from all stations in a division (Guttman \& Quayle 1996). Freshwater flow $\left(\mathrm{m}^{3}\right.$ $\mathrm{s}^{-1}$ ) for the Susquehanna River was obtained from the United States Geological Survey gauging station at the Conowingo Dam (USGS-01578310; http://waterdata. usgs.gov/nwis). Winter (December to February) climate indices for ENSO and NAO were obtained from the National Weather Service, Climate Prediction Center (www.cpc.ncep.noaa.gov). Data on water column properties that influence phytoplankton dynamics $\left(Z_{\mathrm{p}}\right.$, and dis-
Table 1. Meteorological characteristics for weather patterns during the winters of 1989 to 2004. Wind speed and direction based on data from BaltimoreWashington International airport. TA: temperature anomaly; PA: precipitation anomaly; values are means \pm SE. \%: percentage of winter days comprised by relevant weather pattern

\begin{tabular}{|c|c|c|c|c|c|c|}
\hline $\begin{array}{l}\text { Weather } \\
\text { pattern }\end{array}$ & $\%$ & $\begin{array}{l}\text { TA } \\
\left({ }^{\circ} \mathrm{C}\right)\end{array}$ & $\begin{array}{c}\text { PA } \\
(\mathrm{mm})\end{array}$ & $\overline{\text { direction }}$ & Wind $-\overline{\text { speed }\left(\mathrm{m} \mathrm{s}^{-1}\right)}$ & - Conditions \\
\hline $1^{\mathrm{a}}$ & 6.8 & $3.4( \pm 0.46)$ & $1.0( \pm 0.52)$ & W & 3.0 & Warm/wet \\
\hline $2^{b}$ & 17.0 & $-3.4( \pm 0.32)$ & $-0.9( \pm 0.20)$ & NW & 3.7 & Cool/dry \\
\hline $3^{c}$ & 6.1 & $-0.3( \pm 0.48)$ & $0.7( \pm 0.54)$ & $\mathrm{N}$ & 3.4 & Seasonal/wet \\
\hline $4^{c}$ & 4.5 & $2.3( \pm 0.51)$ & $2.5( \pm 0.83)$ & $\mathrm{W}$ & 3.9 & Warm/wet \\
\hline 5 & 17.4 & $2.5( \pm 0.33)$ & $0.4( \pm 0.30)$ & $\mathrm{W}$ & 2.7 & Warm/wet \\
\hline 6 & 7.7 & $-0.1( \pm 0.46)$ & $0.0( \pm 0.43)$ & NE & 2.3 & Seasonal \\
\hline 7 & 13.0 & $-2.1( \pm 0.36)$ & $-0.3( \pm 0.23)$ & W & 4.7 & Cool/dry \\
\hline 8 & 3.3 & $3.2( \pm 0.72)$ & $1.5( \pm 0.83)$ & NE & 2.5 & Warm/wet \\
\hline 9 & 9.2 & $2.1( \pm 0.43)$ & $-0.5( \pm 0.27)$ & $\mathrm{S}$ & 2.0 & Warm/dry \\
\hline 10 & 15.0 & $-1.3( \pm 0.35)$ & $-0.7( \pm 0.21)$ & S & 2.0 & Cool/dry \\
\hline
\end{tabular}




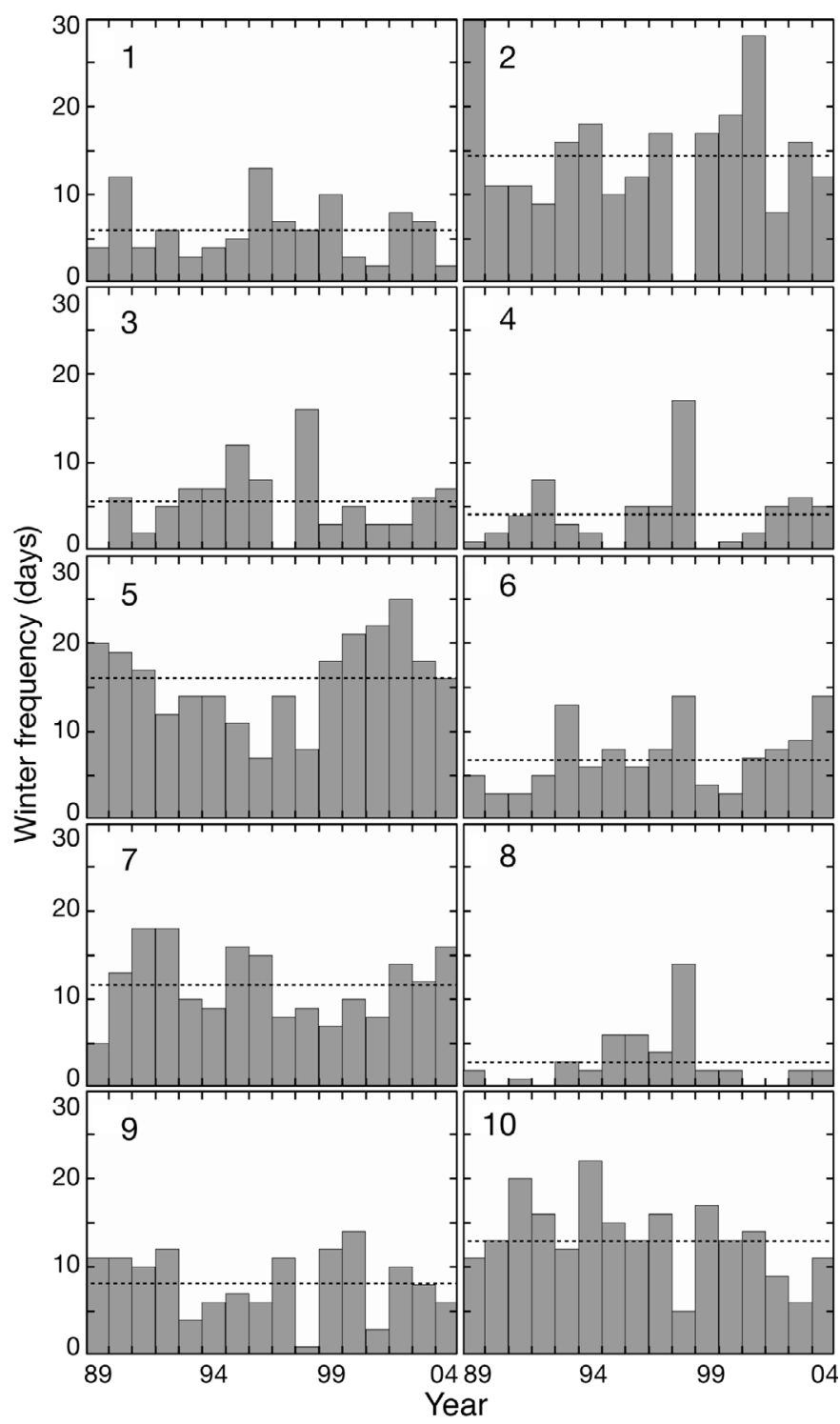

Fig. 3. Time-series (1989 to 2004) of winter (December to February) frequency-of-occurrence for each cluster. Weather pattern number is in upper left-hand corner; horizontal dotted lines: long-term average (LTA) for each weather pattern

\section{RESULTS}

\section{Synoptic climatology}

We identified 10 predominant winter weather patterns using a synoptic climatology classification for the eastern United States (Fig. 2). The resulting maps describe average SLP patterns for all days categorized into a given cluster, showing distinct structures of high and low pressure systems. Each weather pattern corresponded to a unique combination of meteorological conditions, i.e. air temperature, precipitation, wind speed, and direction (Table 1). Patterns 2, 7 and 10 were common in winter, produced below-average temperature $\left(-2.3^{\circ} \mathrm{C}\right)$ and precipitation $\left(-0.7 \mathrm{~mm} \mathrm{~d}^{-1}\right)$, and accounted for $45 \%$ of winter days during the study period. Patterns 1, 3, 4 and 8 were warmer $\left(2.0^{\circ} \mathrm{C}\right)$ and wetter $\left(1.3 \mathrm{~mm} \mathrm{~d}^{-1}\right)$ than average and occurred on only $21 \%$ of the days, but accounted for $32 \%$ of total winter precipitation (Table 1 ).

Interannual variability in the frequencies of the 10 predominant winter weather patterns was high (Fig. 3). Long-term average (LTA; 1989 to 2004) frequencies varied among clusters from a low of $2.8 \mathrm{~d}$ for Weather Pattern 8, to a high of $16 \mathrm{~d}$ for Weather Pattern 5 (Fig. 3). None of the time-series for weather patterns showed statistically significant trends in frequency-ofoccurrence ( $\tau>0.05$, Mann-Kendall trend test). Frequencies of cool/dry weather patterns (2, 7 and 10) varied in concert with one another and in opposition to those of warm/wet weather patterns (1, 3, 4 and 8).

Differences in the frequencies-of-occurrence of warm/wet and cool/dry weather patterns were associated with variability of precipitation and freshwater flow. We compared years with the largest positive and negative differences in frequencies of warm/wet versus cool/dry weather patterns to illustrate this point. Warm/wet years (1990, 1996, 1998, 2003) averaged $13 \mathrm{~d}$ more than the LTA for Weather Patterns 1, 3, 4 and 8 and 9 d less than the LTA for Patterns 2, 7 and 10 (Fig. 4a). Winter-spring (January to April) flow from

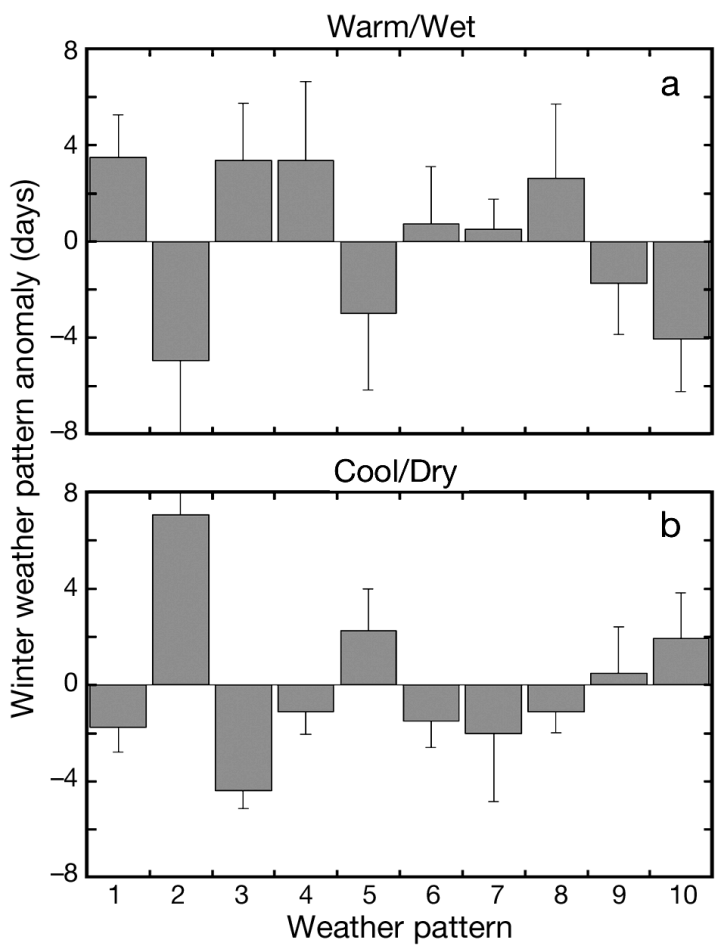

Fig. 4. Winter weather pattern deviations from LTA frequency-of-occurrence for contrasting climate extremes for years dominated by (a) warm/wet and (b) cool/dry weather patterns 
the Susquehanna River averaged $2060 \mathrm{~m}^{3} \mathrm{~s}^{-1}$ for these years, $18 \%$ higher than the LTA. In contrast, cool/dry years $(1989,1991,1997,2001)$ had 8 d less than the LTA for Patterns 1, 3, 4 and 8, and $7 \mathrm{~d}$ more than the LTA for Patterns 2, 7 and 10 (Fig. 4b). Winter-spring flow in cool/dry years averaged $1393 \mathrm{~m}^{3} \mathrm{~s}^{-1}, 20 \%$ lower than the LTA.

Contrasting weather patterns were associated with distinct distributions of light and nutrients $\left(Z_{\mathrm{p}}\right.$, DIN) that influence the spring bloom of phytoplankton in the bay. The LTA for $Z_{\mathrm{p}}$ ranged from 2.5 to $5.4 \mathrm{~m}$ from Region 6 to Region 1, with the deepest $Z_{\mathrm{p}}$ in Region 2. $Z_{\mathrm{p}}$ in cool/dry years ranged from 2.8 to $6.2 \mathrm{~m}$, whereas $Z_{\mathrm{p}}$ in warm/wet years ranged from 1.9 to $4.4 \mathrm{~m}$. Average $Z_{\mathrm{p}}$ was $1.4 \mathrm{~m}$ deeper in cool/dry than in warm/wet years (Fig. 5a). Surface-layer DIN was highest in Regions 5 and 6 closest to the Susquehanna River, and decreased toward the bay mouth (Fig. 5b). The LTA for DIN in these upper bay regions was 60.1 $\mu \mathrm{mol} \mathrm{N} \mathrm{l}^{-1}$. DIN in warm/wet years averaged $71.9 \mu \mathrm{mol}$

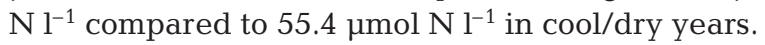

\section{Spring phytoplankton dynamics}

Climate affected the position of the spring phytoplankton maximum, illustrated by 3 biomass measures
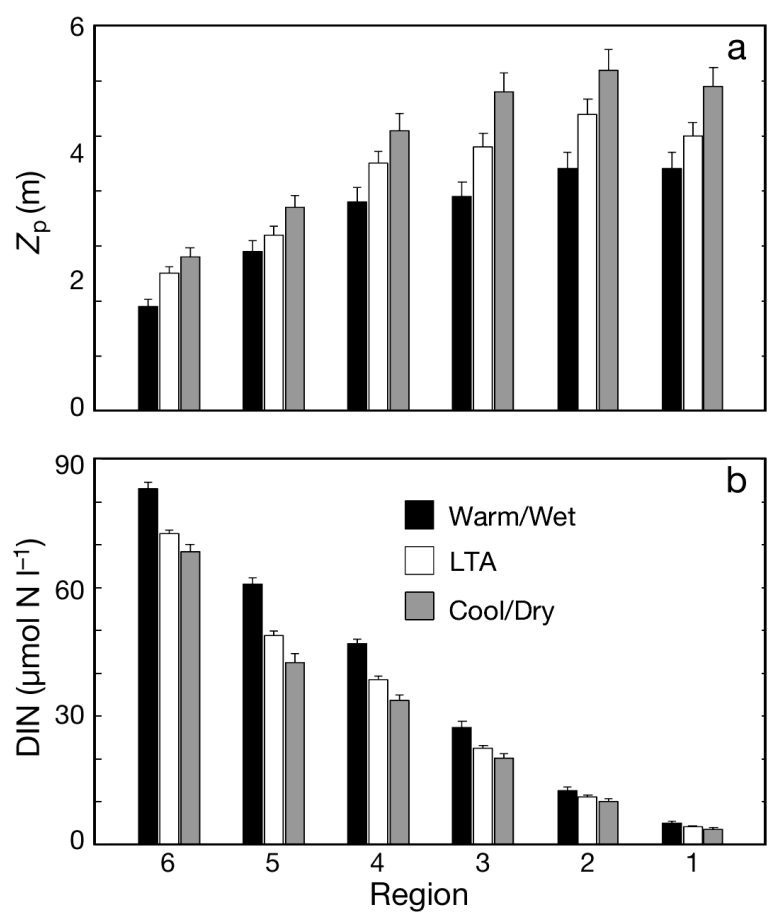

Fig. 5. Regional water column properties (mean $+\mathrm{SE}$ ) for warm/wet, LTA, and cool/dry years for (a) euphotic layer depth $\left(Z_{\mathrm{p}}\right)$ and (b) surface dissolved inorganic nitrogen (DIN).

Regions progress from fresh-water (6) to saltwater (1)
(Fig. 6). During warm/wet years, maxima of $B, B_{\text {eu }}$ and $B_{\mathrm{wc}}$ were seaward of those for cool/dry years. $B$ peaked at $13.1 \mathrm{mg}^{\mathrm{chl} \mathrm{a} \mathrm{m}} \mathrm{m}^{-3}$ in Region 3 for warm/wet years,

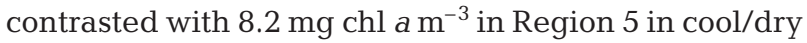
years (Fig. 6a). The $B_{\text {eu }}$ peak occurred in Region 2 for both climate modes, but the magnitude of the peak was greater during warm/wet years than cool/dry

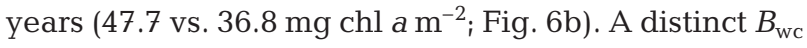
peak occurred in Region 3 during warm/wet years, whereas cool/dry years showed a broad plateau in Regions 3 to 5 (Fig. 6c). Differences between warm/ wet and cool/dry years were greatest in seaward regions (1 to 3 ).
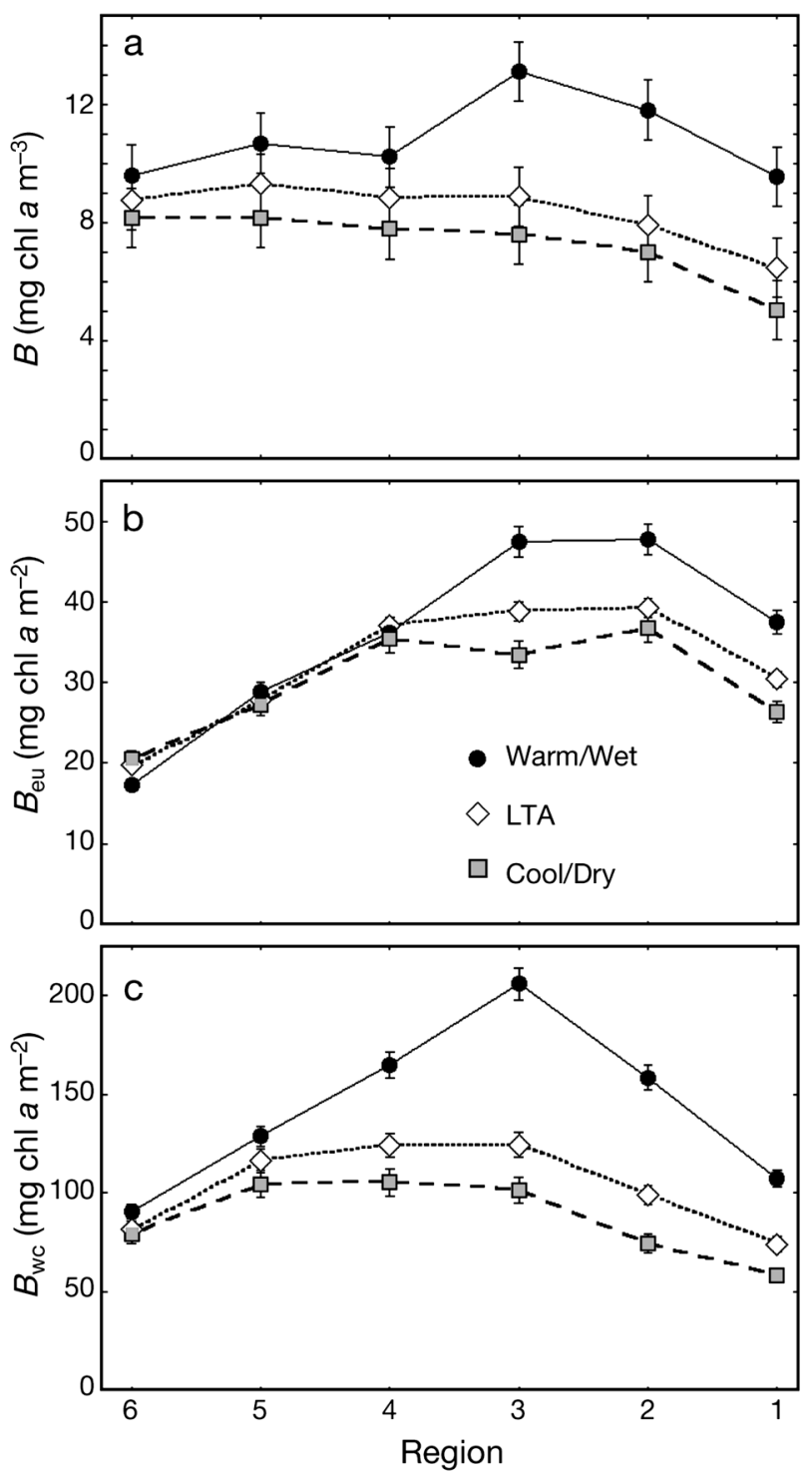

Fig. 6. Regional mean $( \pm \mathrm{SE})$ for (a) phytoplankton $(B)$, (b) euphotic layer $\left(B_{\mathrm{eu}}\right)$, and $(\mathrm{c})$ water column biomass $\left(B_{\mathrm{wc}}\right)$ for warm/wet, LTA, and cool/dry years. Regions progress from freshwater (6) to saltwater (1) 
Differences in $B, B_{\text {eu }}$ and $B_{\mathrm{wc}}$ between cool/dry and warm/wet years, expressed as deviations from the LTA, displayed consistent responses to climate forcing (Fig. 7). The largest positive anomalies for these biomass measures occurred in Regions 1 to 3 during warm/wet years (Fig. 7a,c,e). These regions averaged 49,22 , and $57 \%$ above the LTA for $B, B_{\text {eur }}$ and $B_{\mathrm{wc}}$ respectively. $B_{\text {eu }}$ in Region 6 had a negative anomaly in warm/wet years. The largest negative anomalies occurred in Regions 1 to 3 during cool/dry years. Positive anomalies during warm/wet years were greater than negative anomalies during cool/dry years for each region and biomass measure.

Climate also affected the timing of the spring phytoplankton maximum expressed as total biomass ( $\left.B_{\text {tot }}\right)$. Maximum $B_{\text {tot }} \sim 717$ metric tons occurred in late May during warm/wet years and was significantly greater ( $\mathrm{p}<0.01$ ) than the LTA of 455 metric tons. $B_{\text {tot }}$ had a broad maximum of 383 to 445 metric tons in April and May in cool/dry years and was less $(p>0.05)$ than the LTA (Fig. 8). Spring bloom intensity using this integrated measure of biomass averaged 276 metric tons greater in warm/wet than in cool/dry years.

The spatial extent of high biomass in the Bay also differed in warm/wet and cool/dry climate regimes (Fig. 9). The spatially-averaged, spring mean $B$ was $8.0 \mathrm{mg} \mathrm{chl} a \mathrm{~m}^{-3}$ and the area with $>8 \mathrm{mg} \mathrm{chl} a \mathrm{~m}^{-3}$ averaged $\sim 3800 \mathrm{~km}^{2}$ (Fig. 9b). During warm/wet

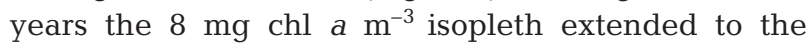

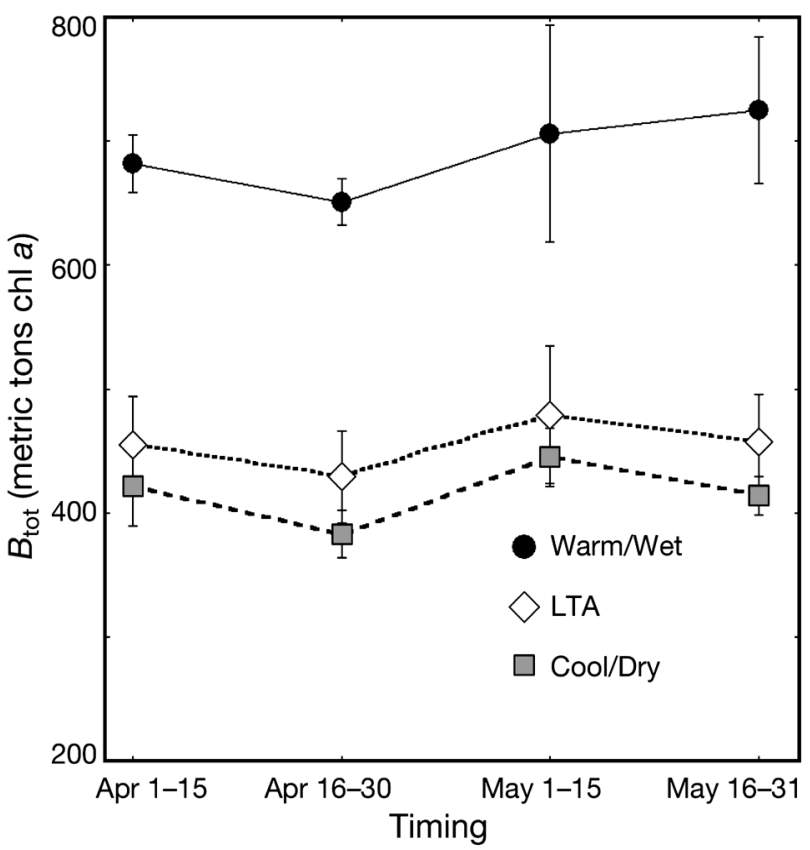

Fig. 8. Timing of maximum total biomass $\left(B_{\text {tot }}\right)$ for warm/wet, LTA, and cool/dry years averaged over 2 wk intervals

Bay's mouth and expanded the area with $B>8 \mathrm{mg}$ chl a m $\mathrm{m}^{-3}$ to $6836 \mathrm{~km}^{2}$ (Fig. 9a). Conversely, during $\mathrm{cool} / \mathrm{dry}$ years the area of $B>8 \mathrm{mg} \mathrm{chl} \mathrm{a} \mathrm{m}^{-3}$ was reduced to $1872 \mathrm{~km}^{2}$ (Fig. 9c).

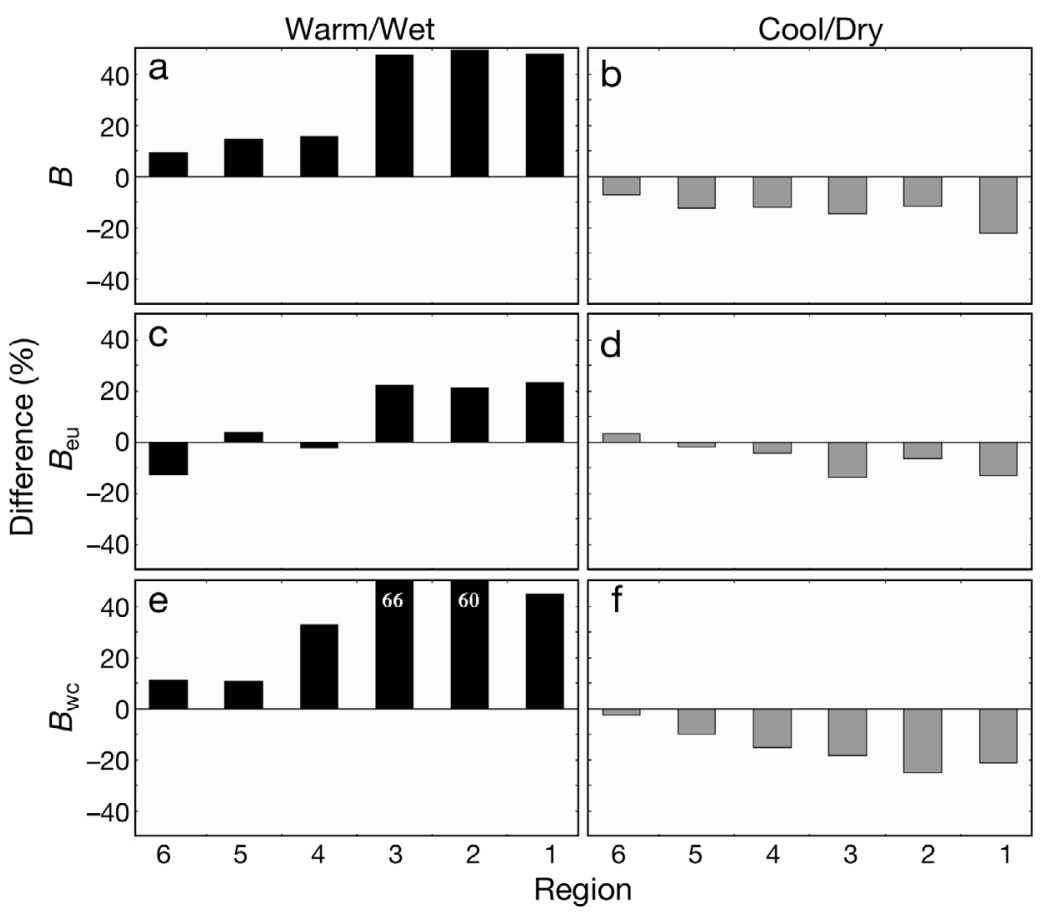

Fig. 7. Percent difference from LTA for 6 regions during warm/wet years and cool/ dry years in $B_{1} B_{\text {eu }}$ and $B_{\mathrm{wc}}$. Regions progress from freshwater (6) to saltwater (1)

\section{Regression models}

Multiple linear regression models using weather pattern frequencies for winter explained 23 to $89 \%$ of the variances of $B, B_{\mathrm{eu}}$, and $B_{\mathrm{wc}}$ for spring (Table 2). These models differed in the weather patterns used to develop the models, the significance of those models, and the amount of variance explained. Model performance measured as adjusted $r^{2}$ was superior in the upper Bay, close to the source of freshwater. For $B$, Weather Patterns 3, 6 and 10 were common predictors in equations that explained an average $56 \%$ of the variance (Fig. 10a). Models of $B_{\text {eu }}$ explained an average $59 \%$ of the variance for all regions and had low error (average RMSE = $6.2 \mathrm{mg} \operatorname{chl~} \mathrm{a} \mathrm{m} \mathrm{m}^{-2}$ ) (Table 2, Fig. 10b). Models of $B_{\text {eu }}$ had Weather Patterns 3, 5, 6, 7 and 9 as common independent variables. $B_{\mathrm{wc}}$ models explained an average of $45 \%$ of the variance, with 


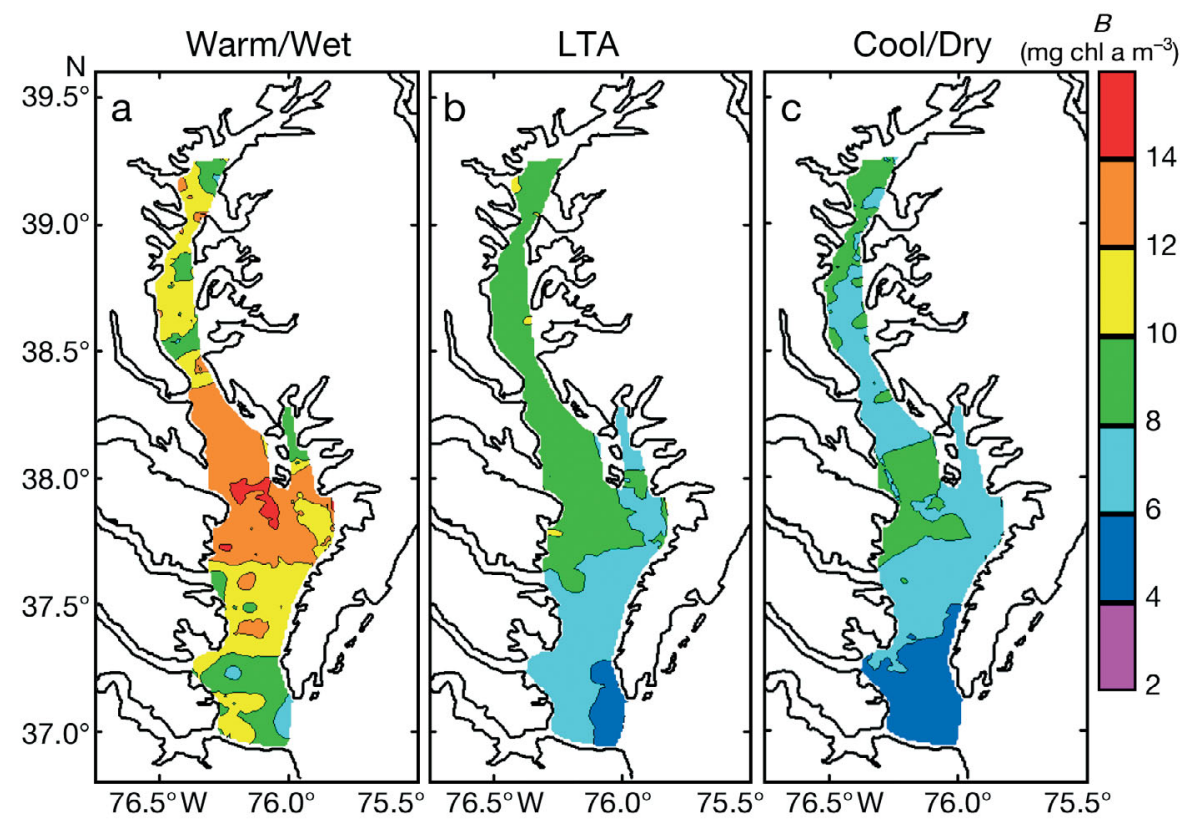

regions of the Bay (Table 2). Overall, Weather Patterns 3, 6, 7 and 9 were the most common independent variables in the 19 models we developed. Winter weather patterns were superior to winter-spring flow, NAO indices, and ENSO indices as predictors of $B, B_{\text {eu }}$ and $B_{\mathrm{wc}}$ for spring, with the exception of $B_{\mathrm{wc}}$ for Region 2, where a linear regression on freshwater flow explained $36 \%$ of the variance $(p<0.01)$.

Time-series of observed and predicted $B, B_{\text {eu }}$ and $B_{\mathrm{wc}}$ for regional models show good agreement of model outputs with data (Fig. 11). Interannual variability in these biomass measures was strongly expressed and was captured very effectively by the models. We detected no systematic under- or overprediction in the models. Posi-

Table 2. Results of multiple linear regression models of winter weather pattern frequencies on measurements of regional spring phytoplankton standing stock. Units for RMSE are mg chl $a \mathrm{~m}^{-3}$ for $B$ (phytoplankton), mg chl $a \mathrm{~m}^{-2}$ for $B_{\text {eu }}$ (euphotic layer) and $B_{\mathrm{wc}}$ (water column), and metric tons chl a for $B_{\mathrm{tot}}$ (total). Weather patterns numbered as in Table 1

\begin{tabular}{|ccccc|}
\hline $\begin{array}{c}\text { Variable } \\
\text { Region }\end{array}$ & $\begin{array}{c}\text { Adjusted } \\
\mathrm{r}^{2}\end{array}$ & $\mathrm{p}$-value & $\begin{array}{c}\text { Weather } \\
\text { patterns }\end{array}$ & $\mathrm{RMSE}$ \\
\hline $\boldsymbol{B}$ & & & & \\
1 & 0.41 & 0.050 & $1,2,3,7,10$ & 1.7 \\
2 & 0.41 & 0.043 & $5,6,9,10$ & 2.1 \\
3 & 0.58 & 0.013 & $1,6,8,9,10$ & 1.8 \\
4 & 0.58 & 0.035 & $2,3,4,5,6,9$ & 1.6 \\
5 & 0.66 & 0.005 & $3,4,6,7,10$ & 0.9 \\
6 & 0.74 & 0.007 & $1,2,3,4,5,7,8$ & 0.9 \\
$\boldsymbol{B}_{\text {eu }}$ & & & & \\
1 & 0.36 & 0.082 & $1,2,3,5,7,10$ & 8.5 \\
2 & 0.72 & 0.008 & $3,4,5,6,7,9,10$ & 5.8 \\
3 & 0.78 & 0.003 & $2,3,6,7,8,9,10$ & 4.6 \\
4 & 0.54 & 0.020 & $3,5,6,8,9$ & 7.5 \\
5 & 0.70 & 0.006 & $1,2,5,7,8,9$ & 4.7 \\
6 & 0.41 & 0.026 & $6,7,9$ & 5.9 \\
$\boldsymbol{B}_{\text {wc }}$ & & & & \\
1 & 0.23 & 0.049 & 1,9 & 21.8 \\
2 & 0.25 & 0.057 & 1,9 & 39.7 \\
3 & 0.44 & 0.031 & $1,2,3,4$ & 35.9 \\
4 & 0.25 & 0.040 & $3,6,10$ & 33.6 \\
5 & 0.65 & 0.011 & $2,3,6,7,8,10$ & 15.5 \\
6 & 0.89 & 0.002 & $1,2,4,5,7,8,9$ & 6.5 \\
$\boldsymbol{B}_{\text {tot }}$ & 0.35 & 0.025 & 1,9 & 146 \\
\hline
\end{tabular}

better results in the upper bay (Regions 5 and 6). Weather patterns 1,2, 3 and 9 were important predictors for $B_{\mathrm{wc}}$ (Table 2, Fig 10c). Weather Patterns 1 and 9 explained $35 \%$ of the variance in $B_{\text {tot }}$ summed for all tive anomalies of warm/wet weather patterns (Fig. 4a) in 1990, 1996, 1998 and 2003 coincided with peaks of $B, B_{\text {eu }}$ and $B_{\mathrm{wc}}$ in most regions. Residuals were generally small and not associated with peaks or troughs in the time-series for these biomass measures. We used the models to remove the climate signal and analyze trends of $B, B_{\text {eu }}$ and $B_{\mathrm{wc}}$ in the 16 yr data set. Residuals showed no significant trends in any of these biomass measures ( $\tau>0.05$; Mann-Kendall trend test).

\section{DISCUSSION}

Synoptic climatology provides a regional alternative to large-scale climate indices as a way to characterize climate variability in the Chesapeake Bay watershed (Stenseth et al. 2003) where NAO and ENSO have limited skill in describing weather (Miller et al. 2006). The weather patterns identified in these analyses (Fig. 2) agree well with literature descriptions of common weather patterns for the area in terms of map structure, seasonality in frequency-of-occurrence, and conditions associated with each pattern (Fig. 3, Table 1; Hayden 1981, Davis et al. 1993). Of particular importance to this work were 4 infrequently occurring patterns $(1,3,4$ and $8 ;<21 \%$ of winter days) that were responsible for $32 \%$ of the precipitation in the region (Table 1). Weather Patterns 3 and 4 represent manifestations of Atlantic Coast 'nor-easters' (Hayden 1981, Davis et al. 1993, Zielinski 2002). While relatively rare in frequency-of-occurrence, these patterns have disproportionate importance because of their potential to deposit significant amounts of snow over much of the 

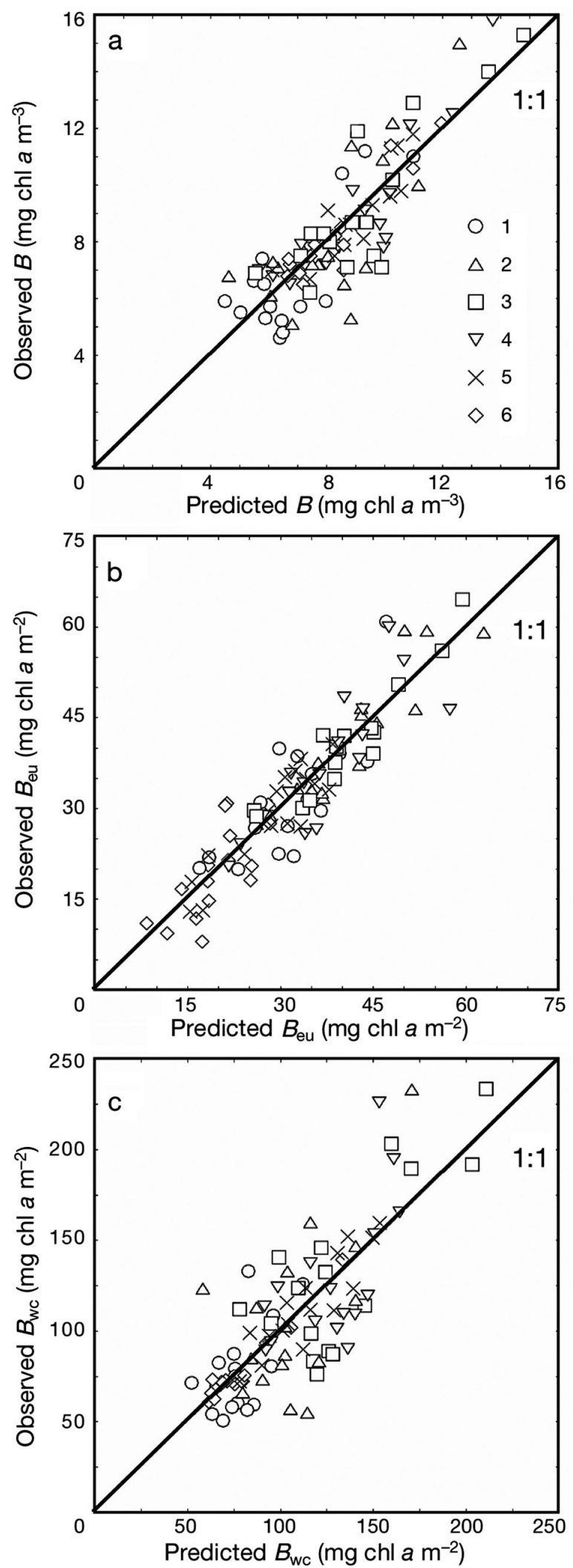

Fig. 10. Comparison of predicted versus observed results from regional multiple linear regression models predicting spring $B, B_{\mathrm{eu}}$ and $B_{\mathrm{wc}}$ watershed. This snow often stays locked in the basin as 'storage' until warmer spring temperatures release the water as part of the spring freshet (Najjar 1999, Miller et al. 2006).

The patterns identified with this approach integrate a number of environmental parameters that influence phytoplankton dynamics, including temperature, precipitation, wind, and irradiance (Table 1; Davis \& Kalkstein 1990), supporting a quantitative analysis of climate variability suitable for regional application (Stenseth et al. 2003). Freshwater input to the Bay has recently been related to variability of these weather pattern frequencies (Miller et al. 2006). There was coherence in the variability of several of the weather patterns described by the synoptic climatology. The frequencies of warm/wet weather patterns (1, 3, 4 and 8) tended to vary in opposition to cool/dry patterns (2, 7 and 10; Fig. 4). Kimmel et al. (2006) showed how these same patterns affect zooplankton abundance, and Austin (2002) described decadal cycles of similar cool/dry and warm/wet weather patterns that affect major fisheries in the Bay.

Climate forcing and associated variability of freshwater flow have been shown to influence phytoplankton dynamics in estuaries. Cloern et al. (2005) demonstrated that a combination of weak coastal upwelling and sustained high pressure over San Francisco Bay produced conditions that led to an exceptional dinoflagellate bloom in September 2004. Smayda et al. (2004) suggested the inverse correlation between mean annual chl $a$ and NAO in Narragansett Bay was related to changes in temperature-dependent grazing. Freshwater flow affects light availability and density stratification in Delaware Bay (Pennock 1985), nitrogen loading to the Neuse River estuary (Rudek et al. 1991), and flushing rate of the Hudson River (Howarth et al. 2000), thereby regulating phytoplankton dynamics in these ecosystems.

The timing, position, magnitude, and extent of the spring bloom in Chesapeake Bay were highly responsive to climate forcing (Figs. 6 to 9). We observed (1) a seaward displacement of the spring bloom in years with greater-than-average frequencies of warm/wet weather patterns (Fig. 6); (2) higher $B, B_{\text {eu }}$ and $B_{\mathrm{wc}}$ in warm/wet years than in cool/dry years, particularly in Regions 1 to 3 (Fig. 7); (3) a $B_{\text {tot }}$ maximum later in spring and significantly higher during warm/wet years than in cool/dry years (Fig. 8); (4) an expanded area with greater-than-average $B$ during warm/wet years (Fig. 9). The responsiveness of the spring bloom to climate is consistent with changes in light and nutrient limitation along the north-south axis of the Bay described in a conceptual view (Harding et al. 2002). In sum, warm/wet years are characterized by reduced light penetration in the upper Bay, and increased nutrient throughput to the 

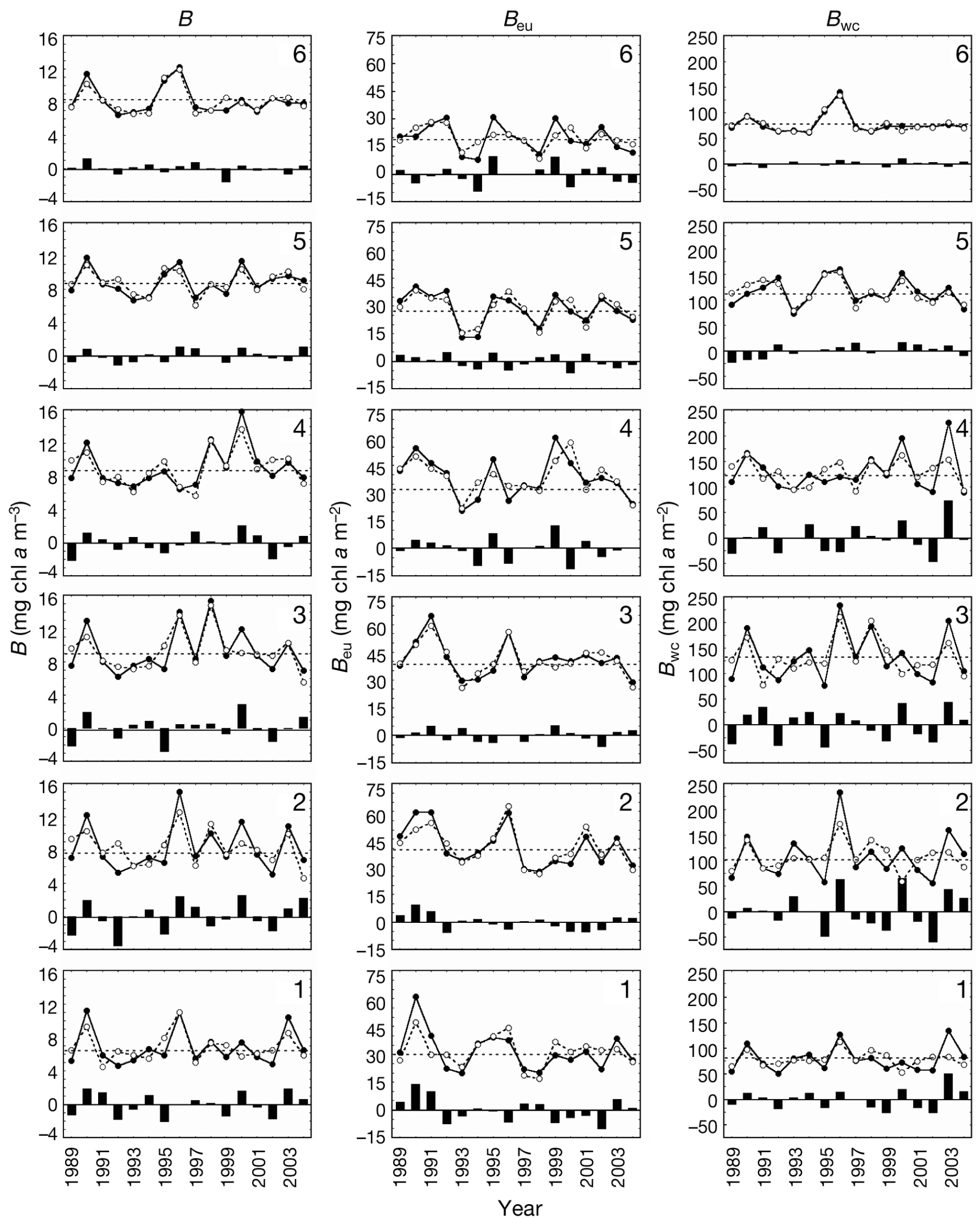

Fig. 11. Time-series of regional predicted $(0)$ and observed $(\bullet)$ results from multiple linear regression models and residuals for $B$, $B_{\mathrm{eu}}, B_{\mathrm{wc}}$. Horizontal dotted lines: LTA for each region; black bars: residuals. Region number is shown in upper right-hand corner 
mid- and lower bay, while the opposite conditions prevail in cool/dry years (Fig. 5; Harding 1994).

Models based on winter weather explained a significant fraction of the variance of $B_{1} B_{\text {eu }}$ and $B_{\mathrm{wc}}$ for spring, supporting our hypothesis that climate forcing underlies interannual variability of the spring bloom (Figs. 10 \& 11). The lagged response whereby winter weather patterns exert a subsequent influence on spring phytoplankton dynamics reflects the role of regional climate variability in controlling freshwater flow and nutrient loading (Miller et al. 2006). Application of synoptic climatology based on a quantitative classification of observed weather patterns to derive predictive models of the spring bloom proved superior to large-scale climate indices such as NAO and ENSO (Table 3), and improves upon previous models based on flow forcing alone (Malone et al. 1988, Harding \& Perry 1997) by capturing the 'holistic' nature of climate variability (Stenseth et al. 2003). The specific weather patterns identified as significant in multiple linear regression models varied because each region and its biomass estimate were uniquely forced by climate. We found biomass measures for the lower Bay to be most sensitive to climate differences (Regions 1 to 3; Figs. 6 \& 7), whereas models for the upper Bay explained more of the variance (Regions 4 to 6 ; Table 2). This is consistent with the exacerbation of light-limitation in the upper Bay in high flow that accompanies warm/ wet weather patterns, and fertilization of the lower Bay wherein nutrient limitation is alleviated (Harding \& Perry 1997, Adolf et al. 2006).

The main contributions of this work were to quantify the direct link between regional climate forcing and spring phytoplankton dynamics in the Bay, and to forecast spring biomass from winter weather. The models we present explained a large fraction of the variance of spring biomass; however, 11 to $77 \%$ remains unexplained. The synoptic climatology used here accurately quantifies the types and frequencies of weather that transit the region, but it is not capable of quantifying the intensity of the weather patterns, and this limitation is a probable source of the unexplained variance in the relationships we derived. Other sources of unexplained variance include (1) climate variability not captured by the synoptic climatology; (2) grazing or trophic interactions not influenced by climate variability; (3) changes in nutrient and sediment loading unrelated to climate, i.e. anthropogenic impacts.

Quantifying the influence of climate variability on phytoplankton biomass with regional models allows an examination of residuals for other sources of variability, such as eutrophication. However, no statistically significant trends in the residuals were observed from any of the regional regression models of biomass measures. This suggests that most of the increase in phytoplankton biomass we can attribute to increased nutrient loading (Harding 1994) occurred prior to the period of this study (1989), and supports the conclusions of Harding \& Perry (1997). Kemp et al. (2005) related this lack of a trend in biomass during the last $20 \mathrm{yr}$ to similar patterns of nutrient loading. Additionally, these results suggest that there has been no reversal of conditions due to management actions. Models of phytoplankton biomass that can account for climate variability may become increasingly valuable if predicted climate change scenarios for the mid-Atlantic are realized (Najjar et al. 2000).

We addressed the hypothesis that differences in regional climate represent the predominant source of interannual variability of spring phytoplankton biomass in Chesapeake Bay. To that end, we have (1) described a procedure and results for classifying and quantifying daily surface SLP to characterize regional climate; (2) quantified the timing, position, magnitude, and extent of the spring bloom for contrasting climate conditions using $B, B_{\mathrm{eu}}, B_{\mathrm{wc},}$ and $B_{\mathrm{tot}}$ determined from a time-series of remotely sensed chl $a$ and products derived from it; and (3) developed multiple linear regression models using the previously described winter weather patterns to describe 4 measures of phytoplankton biomass for spring. These models explained 23 to $89 \%$ of the variability in the regional estimates of phytoplankton biomass. No trends were found in the residual variability of the phytoplankton estimates after the climate signal was removed.

Acknowledgements. The authors thank J. E. Adolf, D. G. Kimmel, M. E. Mallonee, R. J. Wood, and all the pilots and crew of aircraft used in the Chesapeake Bay Remote Sensing Program. Support from NASA, NOAA, EPA and Maryland Sea Grant is gratefully acknowledged. W.D.M. was supported by NASA Headquarters under an Earth System Science Fellowship. Contribution No. 3946 of Horn Point Laboratory, University of Maryland Center for Environmental Science.

\section{LITERATURE CITED}

Adolf JE, Yeager CL, Miller WD, Mallonee ME, Harding LW Jr (2006) Environmental forcing of phytoplankton floral composition, biomass, and primary productivity in Chesapeake Bay, USA. Estuar Coast Shelf Sci 67:108-122

Austin HM (2002) Decadal oscillations and regime shifts, a characterization of the Chesapeake Bay marine climate. Am Fish Soc Symp 32:155-170

Behrenfeld MJ, Randerson JT, McClain CR, Feldman GC and 8 others (2001) Biospheric primary production during an ENSO transition. Science 291:2594-2597

Boynton WR, Kemp WM, Keefe CW (1982) A comparative analysis of nutrients and other factors influencing estuarine phytoplankton production. In: Kennedy VS (ed) Estuarine comparisons. Academic Press, New York, p 69-90

Campbell JW, Esaias WE (1983) Basis for spectral curvature algorithms in remote sensing of chlorophyll. Appl Optics 22:1084-1093 
Cayan DR, Peterson DH (1989) The influence of North Pacific atmospheric circulation on riverflow in the West. In: Peterson DH (ed) Aspects of climate variability in the Pacific and the Western Americas. American Geophysics Union, Washington, DC, p 375-397

Chavez FP, Strutton PG, Friederich GE, Feely RA, Feldman GC, Foley DG, McPhaden MJ (1999) Biological and chemical response of the Equatorial Pacific Ocean to the 1997-1998 El Niño. Science 286:2126-2131

Cloern JE (2001) Our evolving conceptual model of the coastal eutrophication problem. Mar Ecol Prog Ser 210: 223-253

Cloern JE, Alpine AE, Cole BE, Wong RL, Arthur JF, Ball MD (1983) River discharge controls phytoplankton dynamics in the Northern San Francisco Bay estuary. Estuar Coast Shelf Sci 21:711-725

Cloern JE, Schraga TS, Lopez CB, Knowles N, Grover Labiosa $\mathrm{R}$, Dugdale R (2005) Climate anomalies generate an exceptional dinoflagellate bloom in San Francisco Bay. Geophys Res Lett 32:L14608, doi:10.1029/2005GL023321

Cody RP, Smith JK (2005) Applied statistics and the SAS programming language, 5th edn. Pearson/Prentice Hall, Upper Saddle River, NJ

Crane RG, Hewitson BC (1998) Doubled $\mathrm{CO}_{2}$ precipitation changes for the Susquehanna basin: downscaling from the genesis general circulation model. Int J Climatol 18:65-76

Davis RE, Kalkstein LS (1990) Development of an automated spatial synoptic climatological classification. Int J Climatol 10:769-794

Davis RE, Dolan R, Demme G (1993) Synoptic climatology of Atlantic coast north-easters. Int J Climatol 13:171-189

Guttman NB, Quayle RG (1996) A historical perspective of US climate divisions. Bull Am Meteorol Soc 77:293-303

Harding LW Jr (1994) Long-term trends in the distribution of phytoplankton in Chesapeake Bay: roles of light, nutrients, and streamflow. Mar Ecol Prog Ser 104:267-291

Harding LW Jr, Perry ES (1997) Long-term increases of phytoplankton biomass in Chesapeake Bay, 1950-1994. Mar Ecol Prog Ser 157:39-52

Harding LW, Meeson BW, Fisher TR (1986) Phytoplankton in two east coast estuaries: photosynthesis-light curves and patterns of carbon assimilation. Estuar Coast Shelf Sci 23: 773-806

Harding LW Jr, Itsweire EC, Esaias WE (1994) Estimates of phytoplankton biomass in the Chesapeake Bay from aircraft remote sensing of chlorophyll concentrations, 1989-92. Remote Sens Environ 49:41-56

Harding LW Jr, Itsweire EC, Esaias WE (1995) Algorithm development for recovering chlorophyll concentrations in the Chesapeake Bay using aircraft remote sensing, 1989-91. Photogramm Eng Remote Sensing 61:177-185

Harding LW Jr, Mallonee ME, Perry ES (2002) Toward a predictive understanding of primary productivity in a temperate, partially stratified estuary. Estuar Coast Shelf Sci 55:437-463

Hayden BP (1981) Secular variation in Atlantic coast extratropical cyclones. Mon Weather Rev 109:159-167

Howarth RW, Swaney DP, Butler TJ, Marino R (2000) Climatic control on eutrophication of the Hudson River estuary. Ecosystems 3:210-215

Kemp WM, Boynton WR, Adolf JE, Boesch DF and 14 others (2005) Eutrophication of Chesapeake Bay: historical trends and ecological interactions. Mar Ecol Prog Ser 303: $1-29$

Editorial responsibility: Howard Browman (Associate Editorin-Chief), Storebø, Norway
Kimmel DG, Miller WD, Roman MR (2006) Regional scale climate forcing of mesozooplankton dynamics in Chesapeake Bay. Estuar Coast 29:375-387

Mallin MA, Paerl HW, Rudek J, Bates PW (1993) Regulation of estuarine primary production by watershed rainfall and river flow. Mar Ecol Prog Ser 93:199-203

Malone TC (1977) Environmental regulation of phytoplankton productivity in the lower Hudson estuary. Estuar Coast Mar Sci 5:157-171

Malone TC (1992) Effects of water column processes on dissolved oxygen: nutrients, phytoplankton and zooplankton. In: Smith D, Leffler M, Mackiernan G (eds) Oxygen dynamics in Chesapeake Bay: a synthesis of research. University of Maryland Sea Grant, College Park, MD, p 61-112

Malone TC, Crocker LH, Pike SE, Wendler BW (1988) Influences of river flow on the dynamics of phytoplankton production in a partially stratified estuary. Mar Ecol Prog Ser 48:235-249

McCabe GJ, Ayers MA (1989) Hydrologic effects of climate change in the Delaware River Basin. Water Resour Bull 25: 1231-1242

Miller WD, Kimmel DG, Harding LW Jr (2006) Predicting spring discharge of the Susquehanna River from a synoptic climatology for the eastern United States. Water Resour Res 42:W05414, doi:10.1029/2005WR004270

Najjar RG (1999) The water balance of the Susquehanna River Basin and its response to climate change. J Hydrol 219:7-19

Najjar, RG, Walker HA, Anderson PJ, Barron EJ and 12 others (2000) The potential impacts of climate change on the mid-Atlantic coastal region. Clim Res 14:219-233

Ottersen G, Planque B, Belgrano A, Post E, Reid PC, Stenseth NC (2001) Ecological effects of the North Atlantic Oscillation. Oecologia 128:1-14

Pennock JR (1985) Chlorophyll distributions in the Delaware Estuary: regulation by light-limitation. Estuar Coast Shelf Sci 21:711-725

Relexans JC, Meybeck M, Billen G, Brugeaille M, Etcheber $\mathrm{H}$, Somville M (1988) Algal and microbial processes involved in particulate organic matter dynamics in the Loire Estuary. Estuar Coast Shelf Sci 27:625-644

Rudek J, Paerl HW, Mallin MA, Bates PW (1991) Seasonal and hydrological control of phytoplankton nutrient limitation in the lower Neuse River Estuary, North Carolina. Mar Ecol Prog Ser 75:133-142

Smayda TJ, Borkman DG, Beaugrand G, Belgrano A (2004) Responses of marine phytoplankton populations to fluctuations in marine climate. In: Stenseth NC, Ottersen G, Hurrell JW, Belgrano A (eds) Marine ecosystems and climate variation: the North Atlantic a comparative perspective. Oxford University Press, New York

Stenseth NC, Mysterud A, Ottersen G, Hurrell JW, Chan KS, Lima M (2002) Ecological effects of climate fluctuation. Science 297:1292-1296

Stenseth NC, Ottersen G, Hurrell JW, Mysterud A, Lima M, Chan KS, Yoccoz NG, Adlandsvik B (2003) Studying climate effects on ecology through the use of climate indices: the North Atlantic Oscillation, El Niño Southern Oscillation and beyond. Proc R Soc Lond B 270:2087-2096

Yarnal B (1993) Synoptic climatology in environmental analysis. Belhaven Press, London

Zielinski GA (2002) A classification scheme for winter storms in the eastern and central United States with emphasis on 'Nor'easters'. Bull Am Meteorol Soc 83:37-51

Submitted: March 17, 2006; Accepted: June 20, 2006

Proofs received from author(s): January 19, 2007 